\title{
Kualitas Hidup berdasarkan Karekteristik Pasien Diabetes Melitus Tipe 2
}

\author{
Yuli Wahyuni, Nursiswati, Anastasia Anna \\ Fakultas Keperawatan Universitas Padjadjaran \\ E-mail:nursiswati5678@yahoo.com
}

\begin{abstract}
Abstrak
Karekteristik pasien diabetes melitus (DM) tipe 2 yang dapat memengaruhi kualitas hidupnya meliputi umur, jenis kelamin, tingkat pendidikan, sosial ekonomi, lama menderita DM, dan status pernikahan. Tujuan penelitian ini adalah mengetahui gambaran kualitas hidup berdasarkan karekteristik pasien DM tipe 2. Penelitian deskriptif kuantitatif ini melibatkan 89 responden yang diambil menggunakan teknik purposive sampling. Data dikumpulkan menggunakan kuesioner karekteristik responden dan Quality of Life Instrument for Indian Diabetes Patients (QOLID) yang terdiri dari 34 pertanyaan. Data yang terkumpul dikategorikan menjadi kualitas hidup tinggi/rendah berdasarkan nilai mean. Hasil penelitian menunjukkan bahwa kualitas hidup (QoL) pasien DM tipe 2 secara keseluruhan adalah tinggi (56,18\%). Berdasarkan umur, QoL tinggi terbesar adalah lansia $(65,9 \%)$ dan QoL rendah terbesar adalah dewasa madya $(53,84 \%)$. Jenis kelamin, QoL tinggi terbesar adalah laki-laki $(58,97 \%)$ dan QoL rendah terbesar adalah perempuan (46\%). Tingkat pendidikan, QoL tinggi terbesar berada pada perguruan tinggi $(78,26 \%)$ dan QoL rendah terbesar berada pada SD $(65 \%)$. Berdasarkan sosial ekonomi, QoL tinggi terbesar adalah penghasilan lebih dari $>5$ juta $(87,5 \%)$ dan QoL rendah terbesar adalah $<1$ juta $(66,67 \%)$. Berdasarkan lama menderita, QoL tinggi terbesar adalah $>10$ tahun $(66,67 \%)$ dan QoL rendah terbesar adalah $<1$ tahun $(53,33 \%)$. Berdasarkan status pernikahan QoL tinggi terbesar adalah menikah $(56,16 \%)$ dan QoL rendah terbesar adalah janda/duda $(46,67 \%)$. Perawat diharapkan dapat membantu pasien dengan karekteristik tingkat pendidikan SD, usia dewasa madya, penghasilan $<1$ juta dan lama menderita $<1$ tahun dengan cara mengembangkan aktivitas yang dapat mendukung peningkatan QoL pasien DM tipe 2.
\end{abstract}

Kata kunci: DM tipe 2, karekteristik pasien, kualitas hidup.

\section{The Quality of Life of Patient with Type 2 Diabetes Mellitus}

\begin{abstract}
t
Ages, sex, education levels, economic status, marital status, and the length of life with diabetes mellitus are characteristics of patient with type 2 DM that can affect to their quality of life. The purpose of this study was to describe type 2 diabetes mellitus patients' quality of life based on patients' characteristics. Descriptive quantitative approach with purposive sampling was applied to 89 respondents. Data were collected using Quality of Life Instruments for Indian Diabetes Patients (QOLID), which consists of 34 questions. Data were analyzed using means scores. The result showed that quality of life (QoL) of patients with type 2 diabetes were high (56.18\%). Based on age categories, the highest QoL was the elderly group $(65.9 \%)$ and the lowest was the middle adulthood group (53.84\%). Men had higher QoL than women with (58.97\%) and (46\%), respectively. This study also found that university graduates had the highest QoL (78.26\%) and the lowest were elementary school graduates $(65 \%)$. Based on the economic status, people with income $>5$ million $(50 \%)$ had the highest QoL and the lowest was people with income $<1$ million (35.90\%). Diabetic patients who suffering for more than 10 years $(66,67 \%)$ had the highest QoL and the lowest was people who suffer of type 2 DM for less than a year (53.33\%). Based on marital status, the highest QoL was married people (56.16\%) and the lowest was widow (46.67\%). Nurses are expected to help patients with low level of QoL and develop some activities to enhance the QoL of patient with type 2 DM.
\end{abstract}

Key words: Patient's characteristic, quality of life, type 2 DM. 
Yuli Wahyuni: Kualitas Hidup berdasarkan Karekteristik Pasien DM Tipe 2

\section{Pendahuluan}

Diabetes melitus (DM) tipe 2 adalah gangguan metabolisme akibat gangguan produksi insulin atau gangguan pada reseptor (Lewis, 2004). Angka insidensi dan pravelensi DM tipe 2 memiliki kecenderungan peningkatan di berbagai penjuru dunia (PERKENI, 2011).

World Health Organization (WHO) pada tahun 2004 memprediksi adanya kenaikan jumlah penyandang DM di Indonesia dari 8,4 juta jiwa pada tahun 2000, menjadi sekitar 21,3 juta jiwa pada tahun 2030. International Diabetes Federation (IDF) pada tahun 2009 memprediksi kenaikan jumlah penyandang DM dari tujuh juta pada tahun 2009 menjadi 12 juta tahun pada 2030. Terdapat perbedaan angka prevalensi terhadap kedua laporan IDF dan WHO, akan tetapi keduanya tetap menunjukkan adanya peningkatan jumlah penyandang DM sebanyak 2-3 kali lipat pada tahun 2030 (PERKENI, 2011).

Pasien DM baik pada tipe 1 maupun tipe 2 memungkinkan dua jenis komplikasi vaskuler yang, yaitu komplikasi makrovaskuler dan komplikasi mikrovaskuler. Dua jenis komplikasi vaskuler tersebut merupakan komplikasi secara fisiologis yang dialami penderita DM, sedangkan dampak lainnya yang dapat timbul adalah dampak sosial dan psikologis sebagai efek dari pengobatan yang dijalani seumur hidup dan pengaturan makanan yang harus dilakukan setiap hari. Stigma dari masyarakat terhadap pasien DM tipe 2, terutama yang menggunakan terapi insulin memengaruhi kepatuhan pasien dalam melakukan pengelolaan dan upaya pencegahan terhadap komplikasi DM (Vermeire, dkk., 2007). Kondisi stigma masyarakat tersebut berisiko menurunkan kondisi fisik maupun kualitas hidup pasien.

Tujuan pengobatan DM adalah mengurangi risiko komplikasi penyakit mikrovaskuler dan makrovaskuler, memperbaiki gejala komplikasi, dan mengurangi jumlah kasus kematian, serta meningkatkan kualitas hidup penderita DM. Risiko terjadinya komplikasi akibat dari pengelolaan pengobatan dan diet, serta upaya pencegahan komplikasi DM yang kurang tepat dapat berpotensi memengaruhi kualitas hidup penderita DM. Profesional kesehatan seharusnya memberikan perhatian lebih terhadap kualitas hidup penderita
DM karena dapat menjadi salah satu acuan keberhasilan dari suatu intervensi atau terapi (Triplitt dkk., 2005). Pengukuran kualitas hidup juga penting untuk meningkatkan hubungan tenaga kesehatan dengan pasien dan evaluasi pelayanan kesehatan, baik untuk kepentingan penelitian maupun dalam perumusan kebijakan (Rapkin \& Schwartz, 2004).

Perawat merupakan salah satu tenaga kesehatan yang berperan penting dalam mengelola dan mencegah komplikasi DM tipe 2. Intervensi perawat dalam mencegah dan mengelola pasien DM tipe 2 meliputi pengaturan makan, latihan jasmani, dan edukasi. Tercapainya asuhan keperawatan yang komprehensif dalam mengelola dan mencegah terjadinya komplikasi diharapkan dapat meningkatkan kualitas hidup pasien DM tipe 2.

Menurut WHO (2004), kualitas hidup adalah persepsi individu terhadap posisi mereka dalam kehidupan dan konteks budaya serta sistem nilai dimana mereka hidup dan dalam hubungannya dengan tujuan individu, harapan, standar, dan perhatian. Penelitian Nagpal, Kumar, Kakar, dan Bhartia (2010) mengemukakan bahwa terdapat delapan domain kualitas hidup pasien DM tipe 2 yaitu keterbatasan peran karena kesehatan fisik, kemampuan fisik, kesehatan umum, kepuasan pengobatan, frekuensi gejala, masalah keuangan, kesehatan psikologis, dan kepuasan diet. Nagpal, dkk. (2010) lebih lanjut menyebutkan dimensi-dimensi kualitas hidup untuk pasien DM tipe 2 tersebut dapat diukur menggunakan Quality of Life Instrument for Indian Diabetes Patients (QOLID).

Pengukuran respons kualitas hidup pasien DM merupakan penilaian subjektif pada setiap individu. Perbedaan karekteristik antara individu dapat memengaruhi hasil penilaian kualitas hidup. Karekteristik tersebut antara lain jenis kelamin, umur, tingkat pendidikan, status sosial ekonomi, lama menderita, dan status pernikahan (Diener \& Suh, 2000).

Penelitian Wagner, Abbott, dan Lett (2004), menemukan adanya perbedaan yang terkait dengan umur dalam aspek-aspek kehidupan yang penting bagi individu. Beberapa faktor risiko seperti obesitas, kurang aktivitas atau latihan fisik, usia, dan riwayat DM saat hamil menyebabkan tingginya kejadian DM 
Yuli Wahyuni: Kualitas Hidup berdasarkan Karekteristik Pasien DM Tipe 2

pada perempuan (Radi, 2007). Pendidikan dan pengetahuan pasien DM tipe 2 akan berpengaruh terhadap pengontrolan gula darah, cara mengatasi gejala yang muncul, dan mencegah terjadinya komplikasi (Souse, Zauszniewski, \& Musil, 2006). Issa dan Baiyewu (2006) menyatkan bahwa sosial ekonomi merupakan prediktor terjadinya kualitas hidup yang rendah pada pasien DM tipe 2. Status sosial dan ekonomi akan berdampak pada ketersediaan finansial untuk memperoleh pengobatan. DM merupakan penyakit kronis yang pengobatannya sangat mahal dan memerlukan pengobatan seumur hidup serta perawatan diri untuk mencapai kualitas hidup yang tinggi (Ross, Gilmour, \& Dasgupta, 2010).

Penelitian dari Ried dan Walker (2009) menyatakan bahwa lama menderita DM berhubungan dengan tingkat kecemasan pasien, sehingga akan berakibat terhadap penurunan kualitas hidup pasien DM tipe 2. Lama waktu menderita DM dan pengobatan yang dijalani dapat memengaruhi kapasitas fungsional, psikologis, dan kesehatan serta kesejahteraan pasien. Perubahan fisiologis pada keadaan hiperglikemia dalam jangka waktu yang lama menyebabkan komplikasi mikrovaskuler dan makrovaskuler.

Kualitas hidup pasien DM tipe 2 menjadi pening untuk diteliti secara lebih spesifik karena mmberikan dampak yang luas bagi kehidupan. Tujuan penelitian ini adalah untuk memberikan gambaran kualitas hidup berdasarkan karekteristik pasien DM tipe 2 di salah satu rumah sakit negeri di Jawa Barat.

\section{Metode Penelitian}

Penelitian kualitas hidup berdasarkan karekteristik pasien DM tipe 2, menggunakan metode deskriptif kuantitatif. Variabel penelitian ini adalah karekteristik responden dan kualitas hidup pasien DM Tipe 2. Variabel kualitas hidup pasien DM tipe 2 terdiri dari delapan subvariabel, yaitu keterbatasan peran karena kesehatan fisik, kemampuan fisik, kesehatan umum, kepuasan pengobatan, frekuensi gejala, masalah keuangan, kesehatan psikologis, dan kepuasan diet. Karekteristik pasien DM tipe 2 meliputi umur, jenis kelamin, tingkat pendidikan, sosial ekonomi, lama menderita DM tipe 2, dan status pernikahan.

Populasi pada penelitian ini adalah seluruh pasien DM tipe 2 yang berkunjung ke poliklinik endokrin di salah satu rumah sakit negeri di Jawa Barat pada bulan Oktober 2012. Pengambilan data penelitian menggunakan pendekatan purposive sampling. Metode pengambilan data purposive sampling adalah pengambilan sampel yang didasarkan atas pertimbangan dan kesesuaian dengan kriteria inklusi dan eksklusi. Jumlah sampel minimal dalam penelitian ini adalah 89 sampel. Jumlah sampel dihitung menggunakan perhitungan slovin.

Instrumen yang digunakan dalam penelitian ini adalah kuesioner karekteristik responden dan kuesioner kualitas hidup. Kuesioner karekteristik responden pada penelitian ini berupa lembar isian mengenai umur, jenis kelamin, pekerjaan, penghasilan, pendidikan terakhir, status pernikahan, lama menderita, tipe DM, dan komplikasi. Kuesioner kualitas hidup pada penelitian ini diadopsi dari Quality of Life Instrument for Indian Diabetes Patients (QOLID) yang dikembangkan oleh Nagpal, dkk. (2010). Instrumen ini terdiri dari delapan domain yaitu keterbatasan peran karena kesehatan fisik, kemampuan fisik, kesehatan umum, kepuasan pengobatan, frekuensi gejala, masalah keuangan, kesehatan psikologis, dan kepuasan diet. Pertanyaan berjumlah 34 pertanyaan skala likert dengan lima pilihan jawaban, pertanyaan positif berjumlah 10 pertanyaan dan pertanyaan negatif berjumlah 24 pertanyaan. Skor item jawaban berada pada rentang satu sampai dengan lima sehingga skor total berada pada rentang 34 sampai dengan 170 .

Uji validitas construct pada penelitian ini dilakukan oleh ahli bahasa dari lembaga pendidikan Bahasa Inggris dan untuk uji validitas content dilakukan oleh dosen dari Fakultas Keperawatan Universitas Padjadjaran yang ahli dalam bidang diabetes melitus dan kualitas hidup. Uji reliabilitas pada penelitian ini dilakukan pada sepuluh responden pada salah satu Puskesmas di Sumedang dengan hasil uji reliabilitas adalah 0.915 .

Analisis data menggunakan distribusi frekuensi dan nilai rerata untuk menentukan 
Yuli Wahyuni: Kualitas Hidup berdasarkan Karekteristik Pasien DM Tipe 2

Tabel 1 Distribusi Frekuensi Kualitas Hidup berdasarkan Karekteristik Umur (n=89)

\begin{tabular}{lcccccc}
\hline & $\begin{array}{c}\text { QoL } \\
\text { Tinggi }\end{array}$ & \multicolumn{3}{c}{$\begin{array}{c}\text { QoL } \\
\text { Rendah }\end{array}$} & Total \\
\cline { 2 - 7 } & $\mathbf{F}$ & $\mathbf{\%}$ & $\mathbf{F}$ & $\mathbf{\%}$ & $\mathbf{F}$ & $\mathbf{\%}$ \\
\hline Dewasa dini (18-40 tahun) & 3 & 50 & 3 & 50 & 6 & 6,7 \\
Dewasa madya (40-60 tahun) & 18 & 46,15 & 21 & 53,84 & 39 & 43,8 \\
Lansia (>60 tahun) & 29 & 65,9 & 15 & 34,09 & 44 & 49,4 \\
\hline
\end{tabular}

tinggi atau rendahnya kualitas hidup pasien DM tipe 2 peneliti menggunakan nilai mean (130). Peneliti selanjutnya membuat kategori yang terdiri atas kualitas hidup tinggi, jika jumlah total nilai responden $\geq$ Mean (X) dan kualitas hidup rendah, jika jumlah total nilai responden $<$ Mean $(\mathrm{X})$. Setelah diketahui hasil tinggi atau rendahnya kualitas hidup berdasarkan karekteristik pasien DM tipe 2, kemudian data diinterpretasikan dengan menggunakan distribusi frekuensi. Data yang telah diolah disajikan dalam bentuk tabel distribusi frekuensi dan persentase.

\section{Hasil Penelitian}

Hasil penelitian menggambarkan sebagian besar dari responden $(56,2 \%)$ mempunyai nilai kualitas hidup yang tinggi dan yang lainnya mempunyai nilai kualitas hidup rendah. Gambaran kualitas hidup berdasarkan karekteristik pasien DM tipe 2 yang meliputi umur, jenis kelamin, tingkat pendidikan, sosial ekonomi, lama menderita DM tipe 2, dan status pernikahan, diuraikan sebagai berikut:

1. Kualitas Hidup Pasien DM Tipe 2 berdasarkan Karaketeristik Umur di Poli Endokrin di Salah Satu Rumah Sakit Negeri di Jawa Barat Tahun 2013

Tabel 1 menggambarkan persentase terbesar dari responden yang mempunyai nilai kualitas hidup terendah adalah kelompok umur dewasa madya $(53,85 \%)$. Persentase tertinggi responden dengan kualitas hidup tinggi adalah kelompok umur lansia (65,9\%).

2. Kualitas Hidup Pasien DM Tipe 2 berdasarkan Kareketeristik Jenis Kelamin di Poli Endokrin di Salah Satu Rumah Sakit Negeri di Jawa Barat Tahun 2013

Tabel 2 pmenggambarkan persentase terbesar dari responden yang mempunyai nilai kualitas hidup tinggi adalah lakilaki $(58,97 \%)$. Persentase tertinggi dari responden yang mempunyai nilai kualitas hidup rendah adalah perempuan (46\%).

3. Kualitas Hidup Pasien DM Tipe 2 berdasarkan Karekteristik Pendidikan di Poli Endokrin di Salah Satu Rumah Sakit Negeri di Jawa Barat Tahun 2013

Tabel 3 menggambarkan persentase terbesar dari responden yang mempunyai nilai kualitas hidup tinggi berada pada tingkat pendidikan perguruan tinggi (78,26\%). Adapun persentase tertinggi dari responden yang mempunyai nilai kualitas hidup rendah berada pada tingkat pendidikan SD (65\%).

4. Kualitas Hidup Pasien DM Tipe 2 berdasarkan Karekteristik Sosial Ekonomi di Poli Endokrin di salah satu Rumah Sakit Negeri di Jawa Barat Tahun 2013

Berdasarkan tabel 4 dapat diketahui bahwa persentase terbesar dari responden yang mempunyai kualitas hidup tinggi adalah responden dengan status sosial ekonomi yang berpenghasilan $>5.000 .000$ yaitu sebanyak $87,5 \%$. Adapun persentase tertinggi dari responden yang mempunyai nilai kualitas hidup rendah adalah responden dengan

Tabel 2 Distribusi Frekuensi Kualitas Hidup berdasarkan Karekteristik Jenis Kelamin (n=89)

\begin{tabular}{lcccccc}
\hline \multirow{2}{*}{ Jenis Kelamin } & \multicolumn{2}{c}{ QoL Tinggi } & \multicolumn{2}{c}{ QoL Rendah } & \multicolumn{2}{c}{ Total } \\
\cline { 2 - 7 } & $\mathbf{f}$ & $\mathbf{\%}$ & $\mathbf{f}$ & $\mathbf{\%}$ & $\mathbf{f}$ & \% \\
\hline Laki-laki & 23 & 58,97 & 16 & 41,025 & 39 & 43,8 \\
Perempuan & 27 & 54 & 23 & 46 & 50 & 56,2 \\
\hline
\end{tabular}


Yuli Wahyuni: Kualitas Hidup berdasarkan Karekteristik Pasien DM Tipe 2

Tabel 3 Distribusi Frekuensi Kualitas Hidup berdasarkan Karekteristik Pendidikan (n=89)

\begin{tabular}{lcccccc}
\hline \multirow{2}{*}{ Pendidikan } & \multicolumn{2}{c}{ QoL Tinggi } & \multicolumn{2}{c}{ QoL Rendah } & \multicolumn{2}{c}{ Total } \\
\cline { 2 - 7 } & f & \% & f & \% & f & \% \\
\hline Perguruan tinggi & 18 & 78,26 & 5 & 21,73 & 23 & 25,8 \\
SMA & 14 & 52,85 & 13 & 48,15 & 27 & 30,3 \\
SMP & 10 & 58,82 & 7 & 41,18 & 17 & 19,1 \\
SD & 7 & 35 & 13 & 65 & 20 & 22,5 \\
Tidak sekolah & 1 & 50 & 1 & 50 & 2 & 2,2 \\
\hline
\end{tabular}

status sosial ekonomi yang berpenghasilan $<$ 1.000 .000 yaitu sebanyak $33,33 \%$.

5. Kualitas Hidup Pasien DM Tipe 2 berdasarkan Karekteristik Lama Menderita di Salah Satu Rumah Sakit Negeri di Jawa Barat Tahun 2013

Tabel 5 menggambarkan persentase terbesar dari responden yang mempunyai nilai kualitas hidup tinggi berada pada rentang lama menderita $>10$ tahun $(65,67 \%)$. Adapun persentase tertinggi dari responden yang mempunyai kualitas hidup rendah adalah responden pada rentang lama menderita $<1$ tahun $(53,33 \%)$.

6. Kualitas Hidup Pasien DM Tipe 2 berdasarkan Karekteristik Status Pernikahan di Salah Satu Rumah Sakit Negeri di Jawa Barat Tahun 2013

Tabel 6 menggambarkan persentase terbesar dari responden yang mempunyai nilai kualitas hidup tinggi adalah responden dengan status menikah (56,16\%). Adapun persentase tertinggi dari responden yang mempunyai nilai kualitas hidup rendah adalah janda/duda $(46,67 \%)$.

\section{Pembahasan}

1. Kualitas Hidup Pasien DM Tipe 2 berdasarkan Karekteristik Umur
Hasil penelitian ini menunjukkan bahwa adanya persentase terbesar dari responden yang mempunyai nilai kualitas hidup tinggi adalah responden dengan kelompok umur lansia $(65,9 \%)$. Menurut penelitian Wagner, dkk. (2004), terdapat perbedaan yang terkait dengan usia dalam aspek-aspek kehidupan yang penting bagi individu. Hasil penelitian tersebut sejalan dengan penelitian dari Rugerri, Warner, Bisoffi, dan Fontecedro (2001) yang menyatakan bahwa responden berusia tua menunjukkan adanya konstribusi dari faktor usia terhadap kualitas hidup yang dinilai secara subjektif. Hasil penelitian ini menunjukkan bahwa tingginya kualitas hidup pada lansia disebabkan oleh individu pada masa usia tua sudah melewati masa untuk melakukan perubahan dalam hidupnya sehingga mereka cenderung mengevaluasi hidupnya dengan lebih positif. Dewasa madya merupakan masa puncak dimana individu telah mencapai kondisi kesejahteraan secara psikologis, kesehatan, produktivitas, dan keterlibatan dalam masyarakat sangat optimal, oleh karena itu saat krisis terjadi pada usia dewasa madya, seperti terjangkit penyakit, kehilangan pekerjaan, kehilangan pasangan, akan membuat suatu kesedihan yang lebih dalam. Kualitas hidup rendah berada pada kelompok usia dewasa madya. Penurunan kualitas hidup pada usia dewasa madya tersebut dipengaruhi oleh tingginya tuntutan baik dari diri sendiri maupun dari

Tabel 4 Distribusi Frekuensi Kualitas Hidup berdasarkan Karekteristik Sosial Ekonomi (n=89)

\begin{tabular}{lcccccc}
\hline \multirow{2}{*}{ Penghasilan } & \multicolumn{2}{c}{ QoL Tinggi } & \multicolumn{2}{c}{ QoL Rendah } & \multicolumn{3}{c}{ Total } \\
\cline { 2 - 7 } & f & \% & f & \% & f & \% \\
\hline$<1.000 .000$ & 7 & 33,33 & 14 & 66,67 & 21 & 23,6 \\
$1.000 .000-2.000 .000$ & 11 & 45,83 & 13 & 54,17 & 24 & 27 \\
$>2.000 .000-5.000 .000$ & 25 & 69,44 & 11 & 30,56 & 36 & 40,4 \\
$>5.000 .000$ & 7 & 87,5 & 1 & 12,5 & 8 & 9 \\
\hline
\end{tabular}


Yuli Wahyuni: Kualitas Hidup berdasarkan Karekteristik Pasien DM Tipe 2

Tabel 5 Distribusi Frekuensi Kualitas Hidup berdasarkan Karekteristik Lama Menderita DM Tipe $2(\mathbf{n}=89)$

\begin{tabular}{lcccccc}
\hline Lama Menderita & \multicolumn{2}{c}{ QoL Tinggi } & \multicolumn{2}{c}{ QoL Rendah } & \multicolumn{3}{c}{ Total } \\
\cline { 2 - 7 } & f & $\mathbf{\%}$ & f & $\mathbf{\%}$ & f & $\mathbf{\%}$ \\
\hline$<1$ tahun & 7 & 46,67 & 8 & 53,33 & 15 & 16,85 \\
$1-5$ tahun & 20 & 62,5 & 12 & 37,5 & 32 & 36,0 \\
$6-10$ tahun & 13 & 48,15 & 14 & 51,85 & 27 & 30,3 \\
$>10$ tahun & 10 & 66,67 & 5 & 33,33 & 15 & 16,85 \\
\hline
\end{tabular}

lingkungan sekitar mengenai produktivitas dan hubungan sosial masyarakat yang disebabkan oleh manifetasi klinik DM tipe 2. Tingginya tuntutan mengenai produktivitas dan hubungan sosial masyarakat yang tidak terpenuhi memungkinkan individu untuk mempersepsikan kualitas hidup yang rendah (Rapkin \& Schwartz, 2004).

Hasil penelitian ini sejalan dengan penelitian Solli, Stavem, dan Kristiansen (2010) rendahnya kualitas hidup pada lansia dipengaruhi oleh komplikasi penyakit yang dapat meningkatkan ketidakmampuan pasien baik secara fisik, psikologis, dan sosial yang pada akhirnya akan menyebabkan gangguan fungsi tubuh. Tingginya kualitas hidup lansia pada hasil penelitian ini dipengaruhi oleh responden penelitian adalah pasien DM tipe 2 yang tidak memiliki komplikasi seperti penyakit hipertensi, jantung, strok, ginjal, luka diabetik, dan gangguan mata (retinopati). Keadaan responden yang sedang dalam keadaan stabil memungkinkan akan berpengaruh terhadap hasil penelitian persepsi responden terhadap kualitas hidupnya baik.

2. Kualitas Hidup Pasien DM Tipe 2 berdasarkan Karekteristik Jenis kelamin Hasil penelitian ini menunjukkan bahwa persentase terbesar dari responden yang mempunyai nilai kualitas hidup rendah adalah perempuan sebanyak 46\%. Beberapa faktor risiko seperti obesitas, kurang aktivitas atau latihan fisik, usia, dan riwayat DM saat hamil menyebabkan tingginya kejadian DM pada perempuan (Radi, 2007).

Rendahnya kualitas hidup perempuan pada penelitian berkaitan dengan jenis pekerjaan responden. Hampir setengah dari responden sebanyak $43,8 \%$ bekerja sebagai ibu rumah tangga, hal tersebut terkait dengan masalah finansial untuk memperoleh pengobatan. Selain itu, tuntutan pekerjaan sebagai ibu rumah tangga yang memerlukan kekuatan fisik terganggu akibat dari manifestasi klinik yang disebabkan oleh DM.

Peningkatan kualitas hidup perempuan dapat dicapai dengan cara mengoptimalkan kemampuan fisik. Optimalisasi kemampuan fisik tersebut dapat dicapai dengan cara melakukan pendidikan kesehatan pada pasien agar dapat mengenali gejala saat terjadinya hipoglikemik atau hiperglikemik. Setelah mengikuti pendidikan kesehatan tersebut, pasien diharapkan mampu menyesuaikan kondisi kesehatan dirinya dengan jenis pekerjaan yang dilakukakan, serta dapat mengatasi dan mengantisipasi timbulnya gejala klinik dari DM yang akan mengganggu kekuatan fisik.

3. Kualitas Hidup Pasien DM Tipe2 berdasarkan Karekteristik Tingkat Pendidikan berdasarkan Karekteristik Tingkat Pendidikan Persentase kualitas hidup tinggi terbesar berada pada tingkat pendidikan perguruan tinggi yaitu sebanyak 78,26\%. Wahl, Rustoen, Hanested, Lerdal, dan Moum (2004)

Tabel 6 Distribusi Frekeunsi Kualitas Hidup berdasarkan Karekteristik Status Pernikahan Pasien (n=89)

\begin{tabular}{lccccccc}
\hline \multirow{2}{*}{ Status Pernikahan } & \multicolumn{2}{c}{ QoL Tinggi } & \multicolumn{2}{c}{ QoL Rendah } & \multicolumn{2}{c}{ Total } \\
\cline { 2 - 8 } & $\mathbf{f}$ & $\mathbf{\%}$ & $\mathbf{f}$ & $\mathbf{\%}$ & $\mathbf{f}$ & $\mathbf{\%}$ \\
\hline Menikah & 41 & 56,16 & 32 & 43,84 & 73 & 82 \\
Janda/duda & 8 & 53,33 & 7 & 46,67 & 16 & 18 \\
\hline
\end{tabular}


Yuli Wahyuni: Kualitas Hidup berdasarkan Karekteristik Pasien DM Tipe 2

menyatakan adanya pengaruh positif dari pendidikan terhadap kualitas hidup subjektif. Kualitas hidup akan meningkat seiring dengan lebih tingginya tingkat pendidikan yang didapatkan oleh individu. Sejalan dengan penelitian Souse, dkk. (2006), pendidikan dan pengetahuan akan berpengaruh terhadap pengontrolan gula darah, cara mengatasi gejala yang muncul, dan mencegah terjadinya komplikasi sehingga kualitas hidup pasien DM tipe 2 yang berpendidikan tinggi akan terjaga dengan optimal.

Penelitian ini memberikan gambaran tingginya kualitas hidup pada individu yang berpendidikan tinggi adalah mereka cenderung mencari tahu lebih banyak tentang penyakit dari berbagai media informasi. Pengetahuan yang memadai memungkinkan responden dengan pendidikan tinggi akan lebih mengenali masalah frekuensi gejala dan kepuasan diet yang harus dilakukan.

Upaya untuk meningkatkan kualitas hidup pada kelompok responden yang mempunyai pendidikan rendah dapat dicapai dengan cara memberikan pendidikan kesehatan dengan metode yang dapat dipahami oleh pasien misalnya menggunakan media gambar. Pasien juga diharapkan memiliki kartu perkembangan penyakit serta buku panduan yang berisi berbagai informasi mengenai penyakit DM tipe 2, mulai dari tanda dan gejala, komplikasi, jadwal pengobatan, pola makan, cara penyuntikan insulin, latihan jasmani, dan cara untuk mengendalikan gula darah yang ditulis dengan bahasa sederhana dan mudah dipahami. Buku panduan tersebut diharapkan dapat menambah pengetahuan pasien yang lebih banyak mengenai diabetes, sehingga kualitas hidupnya akan meningkat.

4. Kualitas Hidup Pasien DM Tipe 2 berdasarkan Karekteristik Sosial ekonomi Hasil penelitian ini menunjukkan jumlah responden dengan kualitas hidup rendah tertinggi, responden dengan status sosial ekonomi penghasilan $<1.000 .000$ perbulan adalah sebanyak $66,67 \%$. Issa dan Baiyewu (2006) menyatakan bahwa sosial ekonomi merupakan penyebab terjadinya kualitas hidup yang rendah pada pasien DM tipe 2. Karekteristik sosial ekonomi tersebut berkaitan dengan ketersedian finansial untuk memperoleh pengobatan. DM merupakan penyakit kronis yang pengobatannya sangat mahal dan memerlukan pengobatan seumur hidup serta perawatan diri untuk mencapai kualitas hidup yang tinggi (Ross, dkk., 2010). Pentalaksanaan DM menurut (2011) meliputi edukasi, terapi gizi medis, latihan jasmani, dan pengelolaan farmakologis.

Hasil penelitian ini menunjukkan bahwa hampir seluruh responden yang melakukan pengobatan ke poli endokrin di salah satu rumahsakitnegeri diJawa Baratmenggunakan asuransi kesehatan seperti askes, kontraktor, jamkesmas atau program pengobatan gratis lainnya dari pemerintah. Program pengobatan gratis tersebut membantu pasien DM tipe 2 dalam proses pengobatan farmakologis. Penatalaksanaan diabetes yang tidak kalah penting untuk mencapai nilai kualitas hidup tinggi yaitu pengendalian dan perawatan diabetes kurang mendapat perhatian.

5. Kualitas Hidup Pasien DM Tipe 2 berdasarkan Karekteristik Lama Menderita Hasil penelitian berdasarkan karekteristik lama menderita DM menunjukkan kualitas hidup pasien DM tipe 2 mempunyai nilai kualitas hidup tinggi terbesar yang berada pada rentang lama menderita DM $>10$ tahun yaitu sebanyak $66,67 \%$, sedangkan untuk responden yang mempunyai kualitas hidup rendah terbesar adalah responden pada rentang lama menderita $\mathrm{DM}<1$ tahun yaitu sebanyak $(53,33 \%)$. Hasil penelitian $\mathrm{Wu}$ (2007) menyatakan bahwa pasien yang lama menderita $\mathrm{DM} \geq 11$ tahun memiliki efikasi diri yang baik dari pada pasien yang menderita DM $<10$ tahun. Efikasi diri yang baik dapat disebabkan karena pasien telah berpengalaman dalam mengelola penyakitnya dan memiliki koping yang baik.

Hasil penelitian Ried dan Walker (2009) menyatakan bahwa lama menderita DM berhubungan dengan tingkat kecemasan yang dapat mengakibatkan penurunan kualitas hidup. Lama waktu menderita DM dan pengobatan yang dijalani dapat memengaruhi kapasitas fungsional, kapasitas psikologis, tingkat kesehatan, dan tingkat kesejahteraan pasien. Perubahan fisiologis pada keadaan hiperglikemia dalam jangka waktu yang lama akan menyebabkan komplikasi mikrovaskuler dan makrovaskuler pada penderita.

Penelitian Semiardji (2006) menyatakan 
Yuli Wahyuni: Kualitas Hidup berdasarkan Karekteristik Pasien DM Tipe 2

bahwa reaksi pasien DM dalam menghadapi penyakitnya berbeda-beda. Pasien dapat meperlihatkan hal seperti sikap menyangkal, obsesif, marah, frustasi, takut, dan depresi. Respons psikologis orang Indonesia dalam penerimaan terhadap penyakit cenderung lebih baik, hal tersebut dipengaruhi oleh faktor spiritual (Hamid, 2009).

Hasil penelitian ini menunjukkan bahwa hampir setengah dari responden mempunyai nilai kualitas hidup tinggi berada pada rentang lama menderita $>10$ tahun. Hasil penelitian tersebut dipengaruhi oleh aspek penerimaan kondisi pasien yang dilatarbelakangi oleh budaya Indonesia yang mempunyai nilai spiritualitas yang tinggi dan cenderung menghadapi penyakit dengan lebih berserah diri kepada Tuhan.

6. Kualitas Hidup Pasien DM Tipe 2 berdasarkan Karekteristik Status Pernikahan Hasil penelitian berdasarkan karekteristik status pernikahan ini dapat diketahui bahwa responden yang mempunyai nilai kualitas hidup tinggi terbesar adalah responden dengan status menikah sebanyak 56,16\%,. Selanjutnya menurut Wahl, dkk. (2004) mengemukakan bahwa baik pria maupun wanita, individu dengan status menikah atau kohabitasi memiliki kualitas hidup yang lebih tinggi. Pengaruh status pernikahan tersebut terkait dengan dukungan keluarga merupakan indikator paling kuat memberikan dampak positif terhadap perawatan diri pada pasien DM (Neff, dalam Hensarling, 2009).

Penyakit DM dapat memberikan efek psikososial seperti depresi, hal tersebut dapat mengakibatkan pasien menunjukkan sikap negatif dalam pengendalian DM. Sikap negatif tersebut seperti tidak mengikuti diet yang telah diprogramkan, kurang aktivitas fisik, merokok dan kurangnya kepatuhan terhadap pengobatan (Riley, dkk., 2009).

Sikap negatif tersebut dapat diatasi dengan adanya dukungan keluarga. Dukungan keluarga merupakan indikator paling kuat dalam memberikan dampak positif terhadap perawatan diri pada pasien DM (Neff, dalam Hensarling, 2009). Selanjutnya Hause (dalam Setiadi 2008) mengatakan bahwa bentuk dukungan emosional keluarga dapat berupa dukungan simpati, empati, cinta, kepercayaan dan penghargaan. Seseorang yang sedang mempunyai masalah tidak merasa beban untuk dirinya sendiri, tetapi masih ada orang lain yang memperhatikan, mendengarkan dan membantu memecahkan masalahnya. Bentuk perhatian dari pasangan akan meningkatkan perawatan diri pasien DM tipe 2 yang dapat menurunkan risiko komplikasi. Dukungan pasangan seperti mengingatkan dan memantau makanan yang sesuai, mendukung usaha responden untuk olahraga, membantu dalam hal pengobatan, dan memberikan informasi merupakan salah satu hal yang memengaruhi tingginya kualitas hidup pasien DM tipe 2 pada penelitian ini.

\section{Simpulan}

Hasil penelitian ini dapat disimpulkan bahwa secara keseluruhan kualitas hidup pasien DM tipe 2 adalah tinggi, sedangkan kualitas hidup berdasarkan karekteristik responden dapat disimpulkan bahwa sebagian besar berjenis kelamin perempuan dan mempunyai kualitas hidup rendah. Sebagaian besar responden yang mempunyai kualitas hidup tinggi berdasarkan kelompok usia adalah kelompok umur lansia, berdasarkan tingkat pendidikan adalah tingkat pendikan perguruan tinggi, dan berdasarkan status pernikahan adalah pasien yang sudah menikah.

Hasil penelitian ini diharapkan dapat menjadi data untuk meningkatkan kualitas hidup pasien DM tipe 2. Cara yang dapat dilakukan berdasarkan penelitian ini untuk meningkatkan kualitas hidup pasien DM tipe 2 adalah dengan mengembangkan aktivitas yang dapat mendukung peningkatan kualitas hidup pasien DM tipe 2.

\section{Daftar Pustaka}

Diener, E., \& Suh, E. M. (2000). National difference in subjective well-being. In Kahneman, D., Diener, E., \& Scwarz (Eds.), Well being: The foundation of hedonic psychology (pp. 435-450). New York: Russel sage foundation.

Hamid, A. Y. (2009). Bunga rampai asuhan 
Yuli Wahyuni: Kualitas Hidup berdasarkan Karekteristik Pasien DM Tipe 2

keperawatan kesehatan jiwa. Jakarta: EGC.

Hensarling, J. (2009). Development and psychometric testing of hensarling diabetes family support scale (Dissertation degree of Doctor of Philosophy in the Graduate School). Woman's University, Texas.

Issa, B. A., \& Baiyewu, O. (2006). Quality of life of patients with diabetes mellitus in Nigerian Teaching Hospital. Hong Kong College of Psychiatrists, 16, 27-33.

Lewis, K. (2004). Medical surgical nursing assessment and management of clinical problem (5th ed.). St Louis: Mosby Inc.

Nagpal, J., Kumar, A., Kakar, S., \& Bhartia, A. (2010). The development of "quality of life instrument for indian diabetes patients (QOLID): A validation and reliability study in middle and higher income groups. J Assoc Physicians India, 58, 295-304.

Perkumpulan Endokrinologi Indonesia (PERKENI). (2011).Konsensuspengendalian dan pencegahan diabetes mellitus Ttpe 2 di Indonesia. Jakarta : PB Perkeni.

Radi. (2007). Diabetes melitus sebagai faktor risiko penyakit jantung. Diakses dari: http:// www.pjnhk.go.id.

Rapkin, B. D., \& Schwartz, C. E. (2004). Toward a theoretical model of quality of life appraisal: Implications of findings from studies of response shift. Health and Quality of Life Outcomes, 2(1), 14.

Reid, M. K. T., \& Walker S. D. (2009). Quality of life in Caribbean youth with diabetes. West Indian Medical Journal, 58 (3), 250-255.

Riley, McEmtee, M. L., Gerson, L., \& Deninson C. R. (2009). Depression as a co morbidityto diabetes: Implications for management. Journal for Nursing Practioner, 5(7), 523-535.

Ross, N. A., Gilmour, H. L., \& Dasgupta, K. (2010). "14-year diabetes incidence: The role of socio-economic status." Statistics
Canada.

Rugerri, M., Warner. R., Bisoffi, G., \& Fontecedro, L. (2001). Subjective and objective dimensions of quality of life in Psychiatric Patiens: A factor analytical approach. British journal of psychiatry, 178, (p. 168-175).

Semiardji, G. (2006). Stres emosional pada penyandang diabetes. Dalam Sedartawan, S., Pradana, S., \& dan Imam, S (Eds.), Penatalaksanaan diabetes terpadu (hal 337342). Jakarta: Balai penerbit FKUI.

Setiadi. (2007). Konsep dan penulisan riset keperawatan. Yogyakarta: Graha Ilmu.

Solli, O., Stavem, K., \& Kristiansen, I.S. (2010). Health related quality of life in diabetes: The associations of complications with EQ-5D score. Health And Quality of Life Outcomes, 8(18), 1-8.

Souse, V. D., Zauszniewski, J. A., \& Musil, C. M. (2006). Demographic differences of adult with diabetes mellitus cross-sectional study. Online Brazilian Journal of Nursing, $5(2)$.

Triplitt, C. L., Reasner, C. A., Isley, W. L., (2005). Diabetes Mellitus. In: J. T. Dipiro, R. L. Talbert, G. C. Yee, G. R. Matzke, B. G. Wells, L. M. posey (Eds.), Pharmacotherapy, A Pathofisiologic Approach 6th edition (p. 1333-1357). USA: McGraw-Hill Co.

Vermeire, E., Hearnshaw, H., Ratsep, A., Levasseur, G., Petek, D., \& Vandam, H. (2007). Obstacles to adherence in living with type-2 diabetes: an internal qualitative study using meta-ethnography. Primary Care Diabetes, 1,25-33.

Wagner, J.A., Abbot, G., \& Lett. S. (2004). Age related differences in individual quality of life domains in youth with type 1 diabetes. Health and quality of life outcomes, 2(54).

Wahl, A.K., Rustoen, T., Hanested B.R., Lerdal, A., \& Moum, T. (2004). Quality of life in the general Norwegian population, 
Yuli Wahyuni: Kualitas Hidup berdasarkan Karekteristik Pasien DM Tipe 2

measured by the Quality Of Life Scale (QOLS-N). Quality of life research, 13(5), 1001-1009.

Wu, S. F. (2007). Effectiveness of self management for person with type 2 diabetes following the implementation of a self efficacy enhancing intervention program in Taiwan.

WHO. (2004). Introducing the WHOQOL Instrument. Diakses dari hhtp://dept. washington.edi/yqol/whoqol/.infopdf. 